\title{
Urodimento
}

REVISTA DE ESTUDOS EM ARTES CÊNICAS

E-ISSN 2358.6958

\section{Estratégias para sair de si ou de que vida se trata?: Aula online de atuação em tempo de pandemia}

Tatiana Motta Lima

Marcelo Miguez

Valentina Ramos Carcano

Whiverson Reis

Para citar este artigo:

LIMA, Tatiana Motta; MIGUEZ, Marcelo; CARCANO, Valentina Ramos; REIS, Whiverson. Estratégias para sair de si ou de que vida se trata?: Aula online de atuação em tempo de pandemia. Urdimento - Revista de Estudos em Artes Cênicas, Florianópolis, v. 2, n. 41, set. 2021.

doi DOI: http:/dx.doi.org/10.5965/1414573102412021e0126

Este artigo passou pelo Plagiarism Detection Software| iThenticate 
Tatiana Motta Lima²

Marcelo Miguez ${ }^{3}$

Valentina Ramos Carcano 4

Whiverson Reis 5

\begin{abstract}
Resumo
O artigo analisa práticas pedagógicas realizadas na universidade, em aulas de atuação cênica, em ambiente remoto, no período pandêmico. Os estudantes foram convidados a refletir sobre os regimes atencionais mais operantes na sociedade contemporânea, e a investigar, em suas casas e espaços cotidianos, um regime de percepção outro, estruturado em torno do silêncio, da paragem, do alargamento do tempo e da saída de si mesmo na direção dos outros. As experiências criativas individuais gestadas nesse novo ambiente atencional foram analisadas coletivamente, transformando a sala de aula em um laboratório onde a arte se apresentava como um lugar propício à imaginação de mundos outros, menos violentos, individualistas e antropocentrados.
\end{abstract}

Palavras-chave: Processos formativos em arte. Processos criativos. Ensino remoto. Percepção. Laboratório cênico.

1 'Estratégias para sair de si' e 'De que vida se trata?’ são os subtítulos das disciplinas ministradas no primeiro e segundo semestres remotos de 2020. Para fins deste artigo, as duas disciplinas - e suas três turmas aparecerão amalgamadas e os estudantes dos - e os trabalhos realizados nos - dois semestres citados como se fizessem parte de um único curso, já que as questões levantadas e as experiências realizadas tiveram muita semelhança.

2 Professora associada da Universidade Federal do Estado do Rio de Janeiro (UNIRIO), atuando no Departamento de Interpretação e no PPGAC. Diretora do coletivo Hanimais Hestranhos. Membro do Conselho artístico e editorial do CLAPS (Cento Latino Americano de Estudos Stanislávski) tatiana.motta.lima@gmail.com

(9) 1 ttp://lattes.cnpq.br/6549122750769528 (iD https://orcid.org/0000-0003-1081-6890

${ }^{3}$ Formado em Arte dramática pela Escola de Teatro Martins Penna. Bacharelando em Artes Cênicas com habilitação em Atuação Cênica na Universidade Federal do Estado do Rio de Janeiro (UNIRIO).

marcelomiguez.ator@edu.unirio.br

(9ttp://lattes.cnpq.br/3219792054940094 (iD https://orcid.org/0000-0002-9097-6554

4 Licencianda em Teatro pela Universidade Federal do Estado do Rio de Janeiro (UNIRIO). valentina.uni@edu.unirio.br

(9ttp://lattes.cnpq.br/1438699010993585 (iD https://orcid.org/0000-0003-3570-4852

${ }^{5}$ Bacharelado em Atuação Cênica e licenciando em Teatro, ambas pela Universidade Federal do Estado do Rio de Janeiro (UNIRIO). $\quad$ whiversonphr@edu.unirio.br

(9ttp://lattes.cnpq.br/7820741256651275 $\quad$ (iD https://orcid.org/0000-0002-4509-398X 


\title{
Strategies to get out of oneself or Which life is it about?: Online acting classroom in the age of the pandemic
}

\begin{abstract}
Abstract: The article analyzes pedagogical practices carried out at the university, in acting classes, in a remote environment, during the pandemic. Students were invited to reflect on the attentional regimes most operative in contemporary society and investigate, in their homes and everyday spaces, a different perception regime structured around silence, pause, dilated time, and getting out of oneself and moving towards others. The individual creative experiences born in this new attentional environment were collectively analyzed, transforming the classroom into a laboratory where art appeared as a propitious place to imagine other worlds, less violent, individualistic, and anthropocentric.
\end{abstract}

Keywords: Pedagogical processes in art. Creative processes. Online classes. Perception. Scenic laboratory.

\section{Estrategias para salir de uno mismo o ¿de qué se trata la vida?' : La clase de actuación online en tiempo de pandemia}

\section{Resumen}

El artículo analiza las prácticas pedagógicas realizadas en la universidad, en clases de actuación escénica, en un entorno online, durante el período de la pandemia. Se invitó a los estudiantes a reflexionar sobre los regímenes atencionales más operativos en la sociedad contemporánea, e investigar, en sus hogares y espacios cotidianos, un régimen de percepción diferente, estructurado en torno al silencio, la pausa, la prolongación del tiempo y la salida de sí mismo en dirección a los demás. Las experiencias creativas individuales generadas en este nuevo entorno atencional fueron analizadas colectivamente, transformando la clase en laboratorio donde el arte apareció como un lugar propicio a la imaginación de otros mundos menos violentos, individualistas y antropocéntricos.

Palabras-clave: Procesos de formación en el arte. Procesos creativos. Enseñanza remota. Percepción. Laboratorio escénico. 
A pandemia nos separa em nossas casas, em nossas máscaras, em nossos quadradinhos do google classroom de nossa aula não presencial. Por outro lado, a pandemia parece alertar, para quem quiser fazer esse movimento de percepção, para nossa co-dependência e coexistência planetárias, que mais não seja porque nos damos conta daquilo que parecemos ter esquecido: respiramos o mesmo ar. Esse mar invisível que nos envolve é, nesse momento, o que faz com que possamos nos tornar uma ameaça uns para os outros.

Salvo engano, o vírus - e a pandemia - nasceu do deslocamento de determinadas espécies de seu território de vida - dito, habitat natural - por conta da devastação desses territórios com fins mercadológicos. Aqui também, a pandemia dá a ver nossa coexistência com outros seres. E, sem alarmismo, ouvimos de alguns epidemiologistas que essa pode ser apenas a primeira pandemia do século XXI, justamente porque as condições de sua aparição continuam se acentuando no planeta. Trata-se de um modo de pensar, sentir e agir no mundo que, como têm nos alertado as lideranças e xamãs indígenas, pode levar a "queda do céu".

A pandemia, assim, evidenciou uma crise na qual estávamos todos inseridos e fez repensar, de certa maneira, o fluxo global de produtividade e consumo com o qual nos identificamos. Ailton Krenak, em seu livro $A$ vida não é útil, diz assim:

Se nós propusermos para alguém que tem hoje vinte, trinta anos, pôr em questão tudo isso, essa criatura pode falar: "Mas agora que chegou minha vez, você vem me dizer que acabou a festa?". Existe um desejo que essa condição do consumo se estenda por tempo indeterminado, sem que a máquina de fazer coisas precise ser desligada (Krenak, 2020, p.61).

Mas, a máquina foi, senão desligada, ralentada, nem que seja por breves momentos. Ou, ao menos, há areia na máquina. As ruas ficaram mais vazias, ficamos mais tempo em casa e, ao que parece, os rios, mares e o ar apresentaram um menor grau de poluição. Ao mesmo tempo, frente a tantas mortes, o tema do valor da vida e a percepção de que, frente às estruturas nas quais vivemos, há vidas que valem menos - a dos idosos, pobres, negros, indígenas - também ficaram, para os que quiseram ver, ainda mais expostos na pandemia. E, assim, a 
pergunta “De que vida se trata?” feita em sala de aula remota de arte era um questionamento sobre que formas de vida têm merecido cuidado e atenção tanto na cena como no nosso cotidiano.

$\mathrm{Na}$ sala de aula online, havia estudantes que estão, em sua maioria, exatamente entre aqueles vinte e trinta anos dos quais falou Krenak, estudantes dos vários departamentos da Escola de Teatro. Será que estavam desiludidos com o, ainda que parcial, "fim da festa"? Ou, ao contrário, desejosos de imaginar outros mundos? Como pensar junto com eles o fazer artístico nesse mundo que se arruína, ao mesmo tempo que se mostra de maneira mais evidente em suas engrenagens mortíferas? Como pensar o fazer artístico não só no isolamento e na pandemia, mas, de certa maneira, a partir deles? E, ainda, como pensá-lo em casa, no apartamento, na família, no prédio ou, com alguma sorte, no quintal, no jardim?

Desde o início, não nos pareceu possível e nem desejável reproduzir a sala de aula de atuação presencial na sala de aula remota. Por uma série de razões. Em primeiro lugar, queríamos olhar para a paragem, ou melhor, olhar, de dentro da paragem - e das angústias, medos e diferenças que ela suscita -, para o fazer artístico. Assim, queríamos que a sala de aula remota se concebesse conscientemente dentro da pandemia, refletindo sobre seus efeitos em nós.

Além disso, na transição para a sala de aula remota e em tempos de pandemia, apostamos que poderíamos, já que distanciados uns dos outros em nossas cidades, bairros, apartamentos, tecer relações mais efetivas entre os mundos artísticos e cotidianos, em uma espécie de ampliação da "cena" na "casa" e vice-versa. Intuíamos que ao imaginar e experimentar outras maneiras digamos, 'artísticas' - de percebermo-nos em casa, pudéssemos estabelecer uma relação entre as instâncias do cotidiano e da arte, potencializando processos de crítica e transformação. Imaginar mundos diferentes dos mais normatizados, significava, em tempos neoliberais, imaginar maneiras de viver outras do que aquela no qual o capitalismo foi internalizado em modos de pensar, de sentir, de perceber e de agir, nos quais nos reconhecemos e, muitas vezes, nos regozijamos (tanto na arte quanto no dia a dia).

Quisemos convidar os futuros atores e atrizes e, também, os futuros 
professores e professoras de teatro, a participar de processos criativos que questionassem justamente a presença desse modo de subjetivação neoliberal: um eu empreendedor, produtivista, autocentrado e sempre deslocado para o futuro, que está presente também na atuação. Investimos, assim, em buscar "estratégias para sair de si", o que implicava tanto em um convite ao estranhamento de nós mesmos e do mundo em suas normatizações (tantas vezes insidiosas), quanto em uma abertura para aquilo que não é tão facilmente reconhecível como 'eu' ou como 'meu'. Interessava-nos processos criativos, e esse era o ponto focal do trabalho, que ampliassem (ou deslocassem) a percepção que tínhamos de nós mesmos e do mundo, liberando-nos, ainda que momentaneamente, das maneiras mais acostumadas de ver, sentir e nomear. Neste estranhamento, retornávamos à pergunta “de que vida se trata?”, pois percebíamos que havia várias noções de vida em disputa, tanto na cena quanto na cidade.

Essa foi uma maneira de apostar que o período pandêmico, tão doloroso, pudesse animar - verbo que Ailton Krenak utiliza com frequência e beleza -, nas cinzas do presente, uma pequena brasa que, ao mesmo tempo, nos queimasse desnaturalizando nossos hábitos perceptivos e sensíveis - nos aquecesse e iluminasse outras maneiras de estar no mundo.

Nossas leituras e experiências artísticas eram pensadas, assim, como pedaços de carvão levados ao forno. Essa imagem, que acabamos utilizando com frequência, apareceu quando lemos um texto de Peter Brook sobre Shakespeare. Ele dizia:

Shakespeare é um pedaço de carvão que está inerte. Posso escrever livros e dar conferências sobre a origem do carvão - mas meu interesse real no carvão é numa noite fria, quando preciso me aquecer. Levado ao forno, ele se torna o que realmente é (Brook, 1994, p.134).

Brook entende esse "aquecer" muito além da ideia de conforto. Shakespeare aquece porque seus "estranhos desvãos [...], que à primeira vista parecem arcaicos ou remotos, podem, se deixarmos, revelar nossas próprias [da consciência contemporânea] zonas secretas" (Brook, 1994, p.135).

Nas disciplinas, não trabalhamos sobre Shakespeare, nosso escritor guia foi Manoel de Barros. Embora sendo nosso contemporâneo, o poeta também pôde 
nos fazer enxergar algumas de nossas zonas secretas, nos convidando a imaginar mundos diversos daquele em que estamos inseridos e nos quais tivemos nossas subjetividades formadas e forjadas. Barros, na contramão de um mundo regido pela competitividade, produtividade exacerbada e falta de tempo, nos convocava para um mundo das inutilidades, nos convidava a dar atenção aos seres e às coisas desimportantes, nos fazia antever um mundo menos antropocentrado, um mundo de conexões e imersões, de ritmos e convivências, onde seres vivos e não vivos coabitam, onde a lesma "se entrega" à pedra e o "sapo é um pedaço de chão que pula”.

Essa convocação artística e subjetiva era exigente de uma maneira bastante diferente das exigências cotidianas: ela requeria tempo, silêncio, duração, paragem, ruminação, abertura e vulnerabilidade. Demandava uma espécie de amadurecimento para o vazio, um rigor vinculado àquele sair de si, ou como dizia Grotowski ao se referir à noção de via negativa, vinculado àquele "desistir de não fazer" ao invés de "fazer" (Grotowski, 1987, p.15). Vicente Franz Cecim, importante escritor paraense que faleceu recentemente, referindo-se ao seu processo de escrita, falou, em uma live, algo relacionado com aquele amadurecimento que buscávamos: "Eu me deixo me perder de mim no ato de criar para me achar em plena vida" (Cecim, 2020).

Refletir sobre o trabalho da atuação ou, de maneira mais abrangente, sobre o trabalho artístico tendo Manoel de Barros, mas também muitos outros autores como "carvão", foi uma maneira de confrontarmo-nos e de fazer pequenos buracos nessa experiência mais aplainada de vida que se encontra, sem dúvida, também na cena e que ficou ainda mais aparente na pandemia. Sabíamos, desde o começo, que nem a sala de aula de atuação nem o teatro estão protegidos a priori das experiências subjetivas neoliberais, uma vez que nossa imaginação mesmo aquela de artistas, estudantes e professores de arte - está, muitas vezes, conformada a determinadas maneiras de perceber o mundo e de percebermonos nele. Por conta da plasticidade e positividade do capitalismo, não há terreno que se encontre de antemão a salvo.

Ao estudarmos Byung-Chul Han, filósofo sul coreano, que tem se dedicado à crítica da sociedade ocidental, vimos que ele caracterizava o tipo de subjetivação 
contemporânea como aquela do "eu como projeto, que acreditava ter se libertado das coerções externas e das restrições impostas por outros, [mas] submete-se agora a coações internas, na forma de obrigações de desempenho e otimização" (Han, 2018, p.9). Nesse sentido, o sujeito se perceberia "livre" e produtivo, enxergando a si como capital humano. A sala de aula, não estando descolada do mundo, não está separada deste tipo de subjetivação: processos criativos podem, muito rapidamente, transformarem-se em procedimentos produtivos e estudantes e professora em parte dessa máquina de moer gente, mesmo em se tratando do campo da arte.

Por outro lado, parece-nos que é exatamente no campo da cultura e das artes que podemos encontrar um conhecimento acumulado, um conhecimento afetivo, relacional, cognitivo, espiritual e corpóreo de outros modos de estar no mundo, de outros modos de fazer(mo-nos) ou desfazer(mo-nos) sujeitos. Deste conhecimento - sempre experiencial - estávamos sedentos; como se descobríssemos uma possível equipagem para viver em tempos pandêmicos (e imaginar outros tempos).

Nossa sala de aula remota construiu-se, então, a partir de dois movimentos. O primeiro dizia respeito a enxergarmo-nos a nós mesmos; perceber o modo como temos pensado, sentido e agido na vida e na cena. Um movimento autorreflexivo que permitisse a cada um/uma pensar o próprio - e habitual - pensamento, sentir os caminhos - mais mecânicos - dos sentimentos e agir sobre a ação - e agir era, em geral, suspender determinados modos de presença voluntarista, hiperativa e excessivamente autorreferente (que projeta, como sombra, experiências de cansaço, impotência e culpabilização). Esses modos mais acostumados de presença, os víamos ocorrer não apenas na preparação das experiências artísticas, mas também na maneira como líamos um texto literário ou teórico ou como analisávamos os trabalhos criativos uns das outras.

Aquele movimento reflexivo demandava alguma distância não projetiva, pedia por um silêncio daquilo que imaginávamos já saber e convidava a uma autopercepção mais alargada. Nós o chamávamos, na nossa sala de aula, de estudar. Deste movimento, faziam parte tanto os estudantes quanto a professora. Para poder estudar, lemos e ouvimos palestras de pesquisadoras e pesquisadores, 
não sempre do campo da arte, não todo o tempo do campo da academia. Também estudávamos nossas experiências artísticas - as chamávamos de nossos presentes - com aquela mesma disposição autorreflexiva: silenciosa, receptiva e ruminante. E, assim, muitas vezes, a vulnerabilidade e a fraqueza percebidas, no momento pandêmico, como impotência, porque contrariavam a lógica produtivista, podiam ser ressignificadas como abertura e porosidade.

Antes de falar do segundo movimento do curso, é necessário citar alguns autores e autoras ${ }^{6}$ que nortearam nossas discussões. Esses autores foram como bússolas para as questões que deram nome aos cursos. Yves Citton - com sua ecologia da atenção - nos colocou no cerne do problema contemporâneo da atenção/percepção. Historicizando a monetarização de nossa atenção (a sua economia), ele propõe que pensemos em algumas estratégias na direção de uma ecologia da atenção, como, por exemplo, o compromisso com a construção e manutenção de ambientes atencionais diferentes daqueles construídos para e pelo consumo. Nossa reflexão sobre atenção também foi alimentada por Virgínia Kastrup, Maria Cristina Ferraz e Cassiano Quilici. Byung-Chul Han, Pierre Dardot e Christian Laval nos ajudaram na construção da crítica à subjetividade neoliberal. Outro autor importante foi Emanuelle Coccia que com suas noções de imersão, fluxo e coexistência (ao referir-se à vida das plantas) nos convidou a entender a vida em uma dimensão menos antropocêntrica e mais vinculada com ritmos e coabitações. Uma vida que também aparecia nos textos e lives do intelectual e liderança indígena Ailton Krenak, como um convite à participação no que ele chama de "dança cósmica":

...essa experiência da vida como uma dança cósmica, ela sugere que a gente não precisa ficar o tempo inteiro fazendo uma conta sobre o tempo e sobre as condições do agora que a gente está vivendo. A gente pode experimentar o desafio do agora como vida, vida atravessando a gente. [...], o pessoal do teatro e o pessoal da dança toma o corpo como um eixo, quase que experimental, de estar na vida. Eu acho que é óbvio que seja assim, [mas] também podíamos fazer uma experiência de, às vezes, experimentar essa outra coreografia: o movimento que o nosso espírito pode fazer sincronizado com algum sentido para além dessa experiência limitada que temos do corpo (Krenak, 2020).

${ }^{6}$ Nas referências bibliográficas, reunimos, de todos esses autores e autoras citados, os livros e artigos lidos em sala ou apresentados pela professora, e as lives assistidas. 
Por último, Larrosa Bondía ofereceu parâmetros metodológicos para todas as atividades do curso, com seu foco em uma educação baseada na experiência e na alteridade. Esses autores, não vinculados, em sua maioria, ao campo do teatro estrito senso, nos convidaram a pensar a formação de artistas como trabalho ao mesmo tempo poético, ético e político, e a repensar alguns conceitos por vezes já tão desgastados na prática teatral, alargando as suas possibilidades para além dos nossos já conhecidos "muros".

O segundo movimento do curso nasceu na periferia do primeiro e foi tomando um tamanho impensável inicialmente. Eram os nossos presentes: pequenas experiências propostas "para casa” e que, uma vez feitas, eram postadas no mural do classroom, porque estavam destinadas à apreciação de toda a turma.

A ideia, que foi ganhando cada vez mais espaço no curso, foi a de propor a fruição de experiências sensíveis, perceptivas, que demandassem um tempo e uma atenção mais alargados, para serem realizadas nas casas, apartamentos e quintais. Os estudantes eram convidados a realizar estas experiências individualmente e, posteriormente, a preparar a partir delas uma materialidade que pudesse ser partilhável. Buscava-se acessar uma percepção mais silenciosa e alargada, mas também se indagava - e aqui uma nova série de problemas surgia - como preparar algo a partir e/ou através daquela percepção? Como deixar que aquilo que foi experienciado se transformasse em presente, em obra, investigando a relação entre percepção e criação? A cena atoral não era a única finalização criativa possível, os presentes podiam vir em forma de vídeos, colagens, músicas, danças, fotos, podcasts, textos, pinturas e, também, é claro, em forma de cenas de teatro. A escolha era feita pelos estudantes.

Cada uma dessas obras-presentes - tão diferentes entre si - criada individualmente a partir de indicações intencionalmente muito abertas oferecidas pela professora era, posteriormente, analisada pela turma. O trabalho de fruição dos presentes e da reflexão sobre eles era parte importante dos encontros síncronos, transformando a sala de aula em uma espécie de "observatório da (nossa) percepção". No momento da fruição, perguntávamos tanto de que modo poderíamos alargar e refinar nossa percepção como receptores, como também 
por quais caminhos e dispositivos os próprios presentes convocavam (ou não) a esse refinamento.

O convite era também para que nos "intrometêssemos" no trabalho uns dos outros, refletindo sobre cada obra. Não se tratava de emitir um julgamento de valor baseado em gostos individuais. Refletíamos sobre aquela relação entre percepção e criação agora do ponto de vista da recepção. Esforçávamos por não nos projetar demasiadamente sobre as obras-presentes, evitando transformar os apontamentos em uma espécie de falação sobre o eu. Percebemos, inúmeras vezes, esta tendência (e percebê-la também era parte do trabalho) e, quando o aspecto projetivo estava tão forte que não conseguíamos nem mesmo enxergar o presente, recuávamos para uma descrição do que víamos. Olhávamos para os detalhes, para a materialidade; para as cores, as formas, a relação entre os elementos, os ritmos, etc. Outras vezes, experimentávamos fugas das primeiras nomeações através de algumas estratégias: por exemplo, separar som e imagem de um determinado vídeo, percebendo o que se modificava (na própria obra e em nós) a partir dessa separação.

A professora Tatiana Motta Lima, em uma de suas aulas, conduziu o trabalho de análise dizendo assim:

Vamos olhar se eles [os presentes] ajudam ou não a abrir um pouco mais
nossas percepções. Se sim, em que direção elas se abrem? Como
espectadores do presente, vamos olhá-lo nos detalhes e não só
relacionando-o ao conceito ou às primeiras ideias e associações [...] a
gente precisa ter um tempo para usufruir dos presentes, para saborear.
[...] Peço para vocês olharem para os presentes com esse olhar que não
é de entendimento do todo, mas de percepção dos detalhes. Vamos
também tentar imaginar como eles foram preparados, o que teria levado
a esta materialidade? [...] Vamos ainda nos perguntar se eles abriram mais
nossa percepção auditiva, visual ou cinestésica; o que eles fizeram (se
fizeram) no nosso corpo, na nossa pele (Motta Lima, 2020).

Tentávamos localizar e suspender por alguns momentos as maneiras mais normatizadas - projetivas ou de rápida nomeação - de receber a obra-presente para que tivéssemos a possibilidade de abrir outros caminhos para a percepção. Fomos, aos poucos, desbravando e refinando esses caminhos, e entendemos que a percepção é algo que se investiga, se trabalha e se amadurece. Pudemos, por 
exemplo, perceber que um determinado presente havia operado mudanças em nossa respiração: estávamos respirando mais lenta e profundamente. Fomos saindo, assim, da percepção puramente visual ou conceitual da obra-presente e nos dando conta da sensibilização atencional e somática que algumas obras foram capazes de favorecer. E nos perguntávamos, sem ansiar por modelos ou métodos, o porquê e o como isto ocorria.

Não há dúvida que a investigação sobre as noções de contato, adaptação, fluxo, atenção e silêncio, tão importantes para a linhagem artística - Stanislavski, Grotowski, Brook - com a qual vínhamos trabalhando em sala de aula presencial estavam ali referenciadas, tanto em algumas leituras quanto na feitura e apreciação dos presentes. Mas, esse novo formato, no qual o ator e a atriz não eram necessariamente o centro da obra realizada - já que poucos optaram por realizar cenas em que atuavam - permitiu que refletíssemos profundamente sobre os processos de criação atoral. Quando falarmos um pouco mais à frente sobre os presentes veremos que, na sua feitura e apreciação, estávamos, muitas vezes - defeito (ou qualidade) de ofício - refletindo sobre o trabalho do ator e da atriz.

Antes disso, interessa-nos falar sobre o aspecto laboratorial das disciplinas. Acreditamos que essa é uma investigação que tem maior possibilidade de florescer se um certo ambiente de atenção, curiosidade e cuidado for criado também em sala de aula. Investir na criação e manutenção deste ambiente, levando em conta as diferenças e dificuldades impostas pelo ambiente virtual, foi, inicialmente, tarefa da professora e de seus monitores e bolsistas, mas o laboratório só se estabeleceu quando o grupo percebeu a sua importância, dedicando-se a fazê-lo durar no tempo.

Como nossos desejos podem durar no tempo? Esta foi uma das perguntas que surgiu ao longo das disciplinas. Os estudantes falavam tanto da dispersão e dificuldades $^{7}$ do dia a dia, quanto da necessidade de uma espécie de esforço que

Importante dizer que, durante nossos encontros remotos, as dificuldades impostas pela pandemia nunca eram esquecidas: sentimentos - ansiedades, medos - , fatos ocorridos - políticos ou familiares -, e a importância da manutenção da universidade pública e gratuita eram alguns dos assuntos compartilhados pelo grupo nos primeiros minutos de aula. Além disto, para que os estudantes pudessem estar em sala de aula online, foi necessária, ainda que nunca suficiente, a criação de novos editais na Universidade, tanto para compra de equipamentos quanto para o acesso a planos de dados móveis de internet. Mesmo assim, 
era visto como um cuidado para com o curso: relembrar daquele coletivo e de sua investigação, mesmo nos momentos em que não se estava fazendo os trabalhos "para casa" ou em sala de aula remota. Tratou-se, parece-nos, de um processo circular, já que era aquilo que víamos brotar a partir deste ambiente que fez com que quiséssemos protegê-lo. Responsabilizamo-nos mais e mais por ele porque percebemos de maneira experiencial - e não moralizadora - a sua importância para nossas relações e processos criativos e mesmo, para alguns de nós, para nossas vidas numa esfera mais alargada.

Um laboratório também é um lugar para sonhar, inclusive, o que o próprio laboratório pode vir a ser. Um laboratório - mesmo quando há um espaço físico determinado - não é um ambiente dado no qual vamos entrar, mas um ambiente que nasce e se ajusta a partir de nossa convivência. Estar em um laboratório artístico é estar em busca daquilo que não está (já) posto e disposto ao aprendizado; não se trata, portanto, de seguir métodos nem procedimentos anteriormente aprendidos. Essa busca coloca cada uma de nós em um lugar vulnerável, exposto, desconhecido e arriscado. A invenção e manutenção do campo que chamamos "sala de aula" pode oferecer um espaço seguro para essas experiências, não porque nos libertará dos riscos, angústias, frustrações e vulnerabilidades (como promete a indústria do bem-estar), mas exatamente porque irá acolhê-los como parte intrínseca dos processos criativos e, talvez mais importante, como parte intrínseca de nossas vidas.

Estar em laboratório diz respeito também à tentativa de construção de um espaço (do) comum. Aqui, mais uma vez, não se tratou de ter um conceito a priori e aplicá-lo aos estudantes através de, por exemplo, exercícios para formação de grupo. O comum, na sala de aula, foi uma noção experiencial, que esteve em constante ajuste. Parece-nos que, por exemplo, quando compartilhamos um interesse duradouro por determinadas perguntas entrevemos este comum. Mas, é preciso ficar atento às singularidades (ou não) das respostas construídas para estas indagações, atentos também àquilo que seria muito rapidamente julgado como erro ou como compreensão equivocada das perguntas iniciais (pois, muitas

vivemos dificuldades como instabilidade e mesmo queda da internet em algumas casas, o que nos deixava entre a incerteza se o/a estudante retornaria ou perderia uma parte de nosso encontro, e a esperança por seu retorno. 
vezes, nesses "erros" há inúmeras possibilidades!). Buscamos, portanto, construir o comum, em nossa sala virtual, justamente nas respostas singulares - e não na repetição de modelos - e nos ajustamentos que as perguntas iniciais sofriam no contato com cada um, com cada uma de nós. O comum se fez também no acordo de uma pertença coletiva dos materiais: certas vezes, algo que começava a ser investigado por um aluno pôde ser reelaborado ou continuado por outra; é que, uma vez às obras-presentes oferecidas à turma, o material passava a ser um lugar de consulta e inspiração para todos os estudantes e para a professora.

Na análise que fazíamos dos presentes, também apostamos na construção daquele comum. Era importante que todos tivessem a experiência de falar sobre o trabalho do outro e de ouvir sobre seu próprio trabalho. Tratava-se de mais um desafio à nossa percepção. Ouvimos o que os outros falam? Ouvimos o que nós mesmos falamos? O laboratório deve ser um lugar seguro, onde tanto quem vai ouvir sobre o seu presente como quem reflete sobre o presente do outro não se sinta julgado, mas perceba-se como participante de uma espécie de aventura ou de expedição na direção de um falar/ouvir mais expandido. A segurança nasce de um determinado tipo de cuidado, diferente daquele mais socialmente conhecido, complacente ou preocupado em não desagradar: um cuidado que busca perceber o quê e o como falar. Para isso, é necessário perceber-se diante de sua própria fala (ou de seu modo de escutar a fala do outro), perceber quem (em mim) fala ou ouve ou, ainda, quem (em mim) percebeu aquilo sobre o qual resolveu falar.

Fala e escuta nascem de inúmeros processos inconscientes, projetivos, relacionais, e alguns deles podem ser estudados se não nos identificarmos totalmente com aquele que fala ou escuta em nós, se ganharmos uma espécie de distância afetiva, se pudermos perceber a nós mesmos enquanto falamos e ouvimos. Esse é também um processo coletivo, pois, já que a fala e a escuta tocam as subjetividades, elas fazem coisas com o próprio grupo; coisas que devem ser percebidas pelo coletivo. Falar e escutar são experiências que requerem atenção e ajustes.

Concluímos que falar (ou ouvir) e perceber-se nestes gestos podem fazer parte daquela mesma ação de estudar-se e de permitir estranhar-se a partir da relação com os outros. O laboratório é, assim, um organismo vivo, uma vida que 
só vive nos ajustes, um comum que se realiza fora dos dogmas ou prévias certezas, já que é no inacabamento dos sujeitos que se constrói a relação, e não nos indivíduos previamente ditos (e ouvidos), previamente conhecidos.

Nesse ambiente, também as leituras da bibliografia podem ganhar um outro sabor. Ao ler, investigamos o próprio ato da leitura. Buscamos imaginar para esse ato, às vezes tão "machucado" pelas experiências escolares pelas quais os estudantes passaram, outras possibilidades. Não se trata nem de alimentar-se de conteúdos nem, o que tem sido comum também na educação dita mais moderna, de projetar-se sobre os textos perguntando-se onde (isto) (me) serve ou me toca, etc.

Buscamos, com Jorge Larrosa Bondía, um ler/estudar nascido na noção de diferença, de alteridade, um aprender que pode ser percebido como uma visitação que nos coloca em risco de transformação. Larrosa vê a leitura de modo radical. Para ele, "o importante, a partir do ponto de vista da experiência, é como a leitura [...] pode ajudar-me a dizer o que ainda não sei dizer, o que ainda não posso dizer, ou o que ainda não quero dizer” (Bondia, 2011, p.10-11). Diz ainda:

Poderia falar-se, então, de uma alfabetização que não tem a ver com ensinar a ler no sentido da compreensão, senão no sentido da experiência. Uma alfabetização que tenha a ver com formar leitores abertos à experiência, a que algo lhes passe ao ler, abertos, portanto, a não se reconhecer no espelho (Bondia, 2011, p.9, grifo nosso).

Pensávamos, a partir deste convite de Bondía, também sobre as outras atividades que realizávamos em sala de aula ou em casa: como poderíamos criar a partir dessa abertura, nos deixando afetar pelo que vem de fora, pelo que não previamente procuramos ou propomos? Como pensar uma criação que não nascesse de "mim", mas de algo que me passa? E ainda: como esse modo de criar poderia afetar o fazer atoral? Se a cena fosse lugar do que não (re)conheço, que cena seria essa? E que preparação de ator e de atriz esta cena demandaria?

Na avaliação do curso, o estudante Igor Nascimento faz uma relação entre a experiência da leitura e os exercícios práticos para casa, os presentes. Perguntase: "De que forma eu utilizo o texto para criar movimento? É como se eu deixasse que o movimento que ele [texto] causa dentro de mim durante a leitura, saísse 
para fora”.

A sala de aula, como laboratório, tem a possibilidade de se transformar em um "ambiente atencional" (Citton, 2017) diferente daquele no qual estamos acostumados a viver. E, nesses semestres, vimos que esse ambiente atencional pôde expandir-se para nossas casas. Consideramos, assim, nossos lares como o lugar da investigação e estranhamos os espaços nos quais moramos e nossas relações cotidianas com eles e com os outros seres que lá habitam. Esses locais, que outrora passavam despercebidos ou eram habitados de maneira utilitária e habitual, passaram a ser vistos como lugares de pesquisa, começaram a se tornar matéria-prima para nossos presentes e para muitas discussões que também diziam respeito ao trabalho do ator e da atriz em cena.

Fomos descobrindo durante este tempo como realizar um laboratório de maneira remota e como ele podia realizar-se a partir daquilo que a pandemia estava nos fazendo sentir e viver. Talvez estivéssemos buscando aquilo que a aluna Beatriz Charles em seu texto final de avaliação disse ter vivenciado: "a construção de um espaço de sala de aula dentro de nós". Aqueles movimentos de estudar e estudar-se, a abertura para uma percepção menos mecanizada, a criação que se relaciona com os movimentos da vida, tudo isso nos acompanhava também nas vivências familiares e cotidianas. E, de certa forma, nos equipava para a pandemia. Tratava-se de uma equipagem muito sutil, mas nem por isso menos efetiva, feita de atenção, porosidade, silêncio e vulnerabilidade.

Antes de mostrar alguns de nossos presentes, vamos compartilhar duas tirinhas, uma da Laerte e outra de Liniers, um desenho de Manoel de Barros e uma música de Gilberto Gil. Através dessas quatro criações, introduzimos em sala de aula as questões que discutimos de maneira mais profunda e mais ampla durante todo o curso.

Nosso intuito era pensar sobre os subtítulos das disciplinas - "estratégias para sair de si" e "de que vida se trata?" - de uma maneira mais sensível do que conceitual. Na continuidade do curso, as noções reapareceram de modo conceitualmente rigoroso, porém, para abrir os trabalhos nos interessava estímulos que operassem mais como um chamado do que como uma prévia 
nomeação. Os títulos das disciplinas já tinham este intuito, mas colocar imagens e som nestes títulos nos pareceu uma boa estratégia pedagógica.

Na tirinha desenhada por Laerte (figura 1), uma moça está desenhando uma flor que ainda é um broto. Com o passar do tempo, nos dois quadrinhos seguintes, a flor vai crescendo, se modificando, se transformando em árvore com flores e frutos. No último quadrinho, a desenhista solicita à planta que "pare quieta um segundo" para que ela possa continuar a desenhá-la.
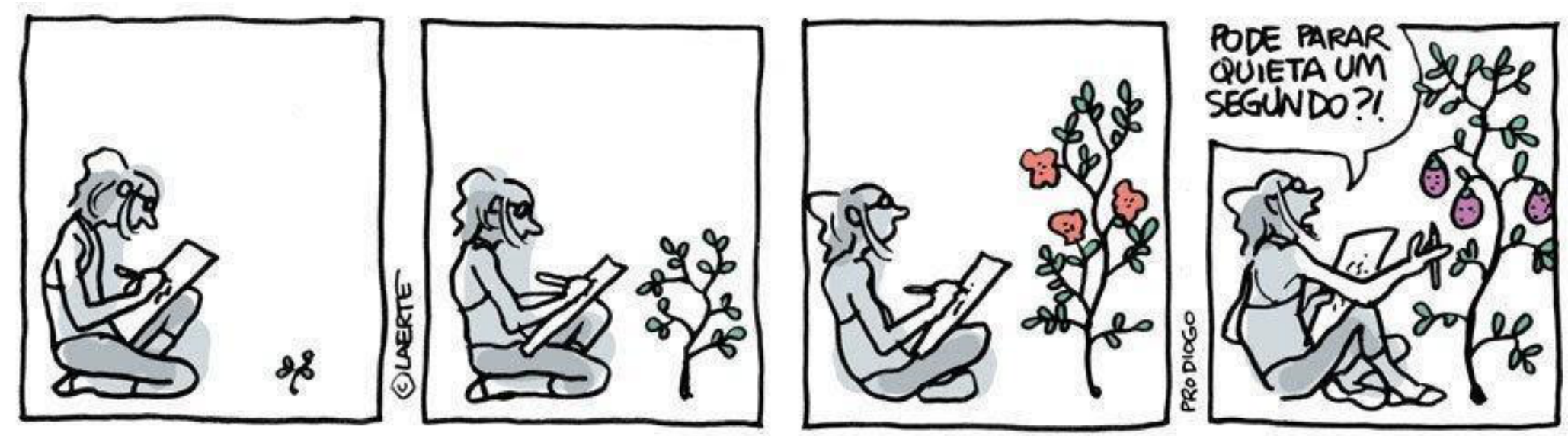

Fonte: revista projeto, $2014^{8}$

Na segunda tirinha (figura 2), vemos uma menina deitada na mesma posição, observando, pelo "tempo" de dois quadrinhos, uma folha que voa. Em seguida, a jovem senta-se e dirige-se à folha perguntando onde ela havia aprendido a dançar.

Disponível em: https://revistaprojeto.com.br/noticias/mostra-homenageia-laerte-coutinho-sao-paulo/. Acesso em: 10 jun. 2021. 


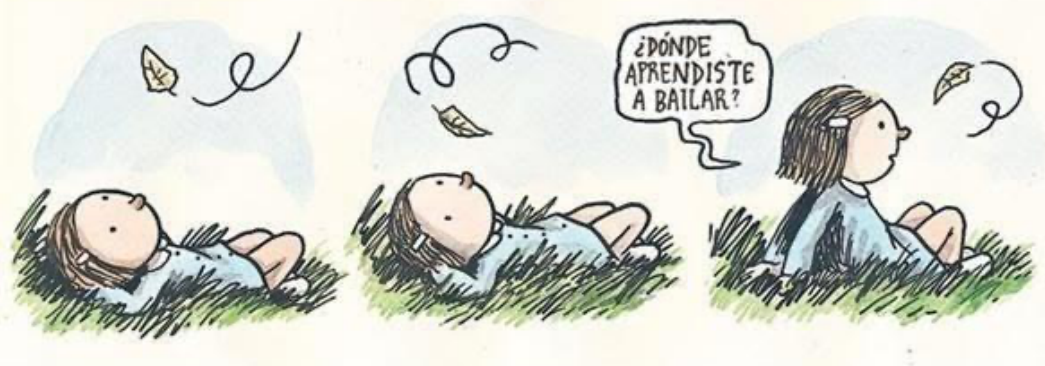

Fonte: Blog do quadrinista Liniers ${ }^{9}$

O desenho apresentado à turma é do poeta Manoel de Barros (Figura 3). Nele, vê-se uma figura humana. Seu braço esquerdo se parece com um galho fino e, nele, um passarinho está pousado. Também sua cabeça não está em cima de um pescoço, mas parece pousar sobre o que seria o outro braço, um retângulo fechado (um pequeno tronco?). O corpo da figura é feito de mais dois retângulos superpostos colocados em cima de duas canelas e de dois pés.

Figura 3: Desenho de Manoel de Barros

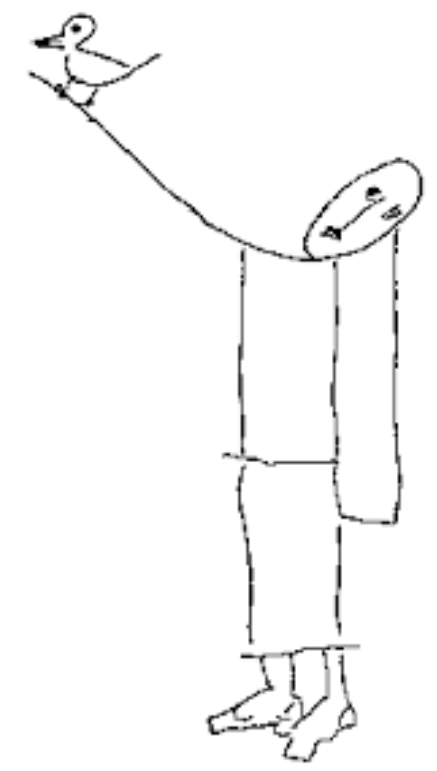

Fonte: Templo Cultural Delfos ${ }^{10}$

${ }^{9}$ Disponível em: http://macanudoliniers.blogspot.com/. Acesso em 11 jun. 2021.

10 Disponível em:

http://www.elfikurten.com.br/2011/02/manoel-de-barros-natureza-e-sua-fonte.html?m=1. 
Por último, ouvimos a música de Gilberto Gil, cantada por Dominguinhos e Elba Ramalho e lemos sua letra:

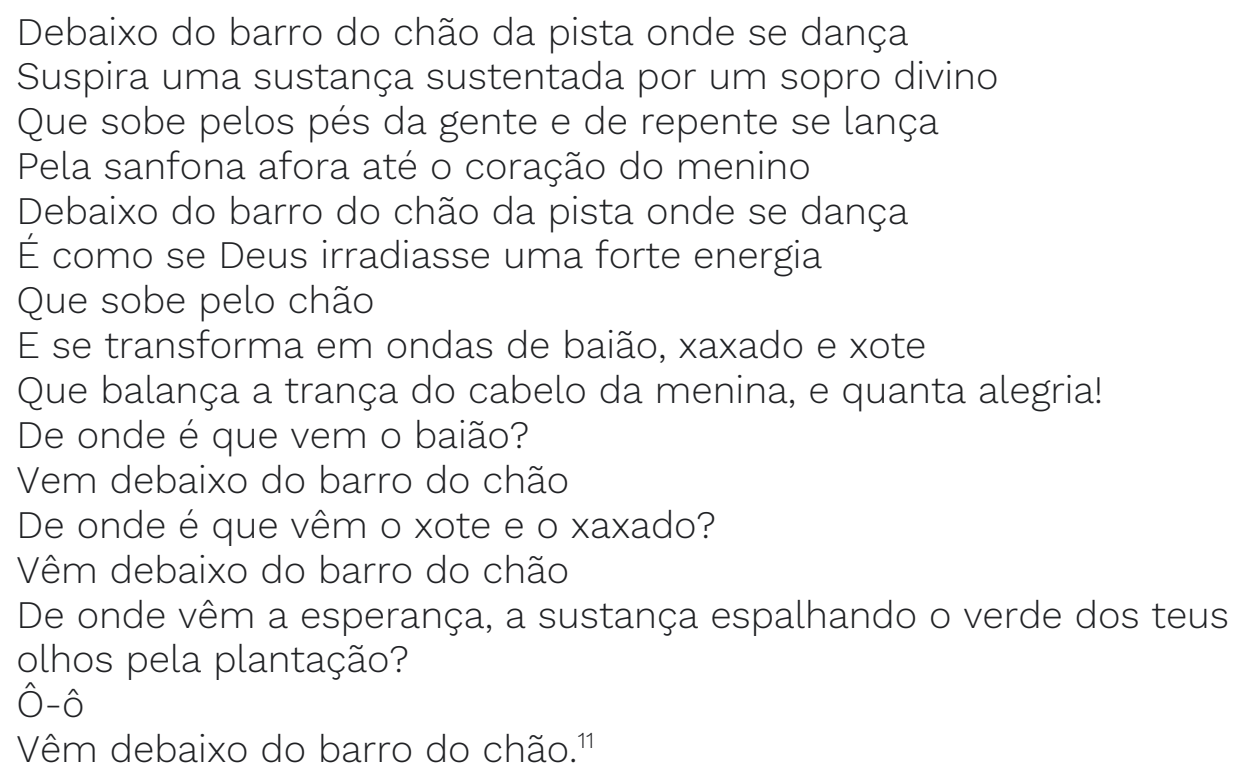

Na sala de aula, apresentamos uma obra de cada vez e pedimos para os alunos e alunas refletirem sobre o que percebiam, tentando relacionar esta percepção com os temas/títulos que tínhamos apresentado antes. Neste artigo, interessa-nos trazer esta reflexão em um único bloco. Não se tratou e nem se trata agora de analisar as obras, mas de deixá-las operar fazendo pequenas ligações sensíveis e poéticas com os temas dos cursos, tratá-las como uma espécie de lugar em comum - não finalizado - ao qual pudéssemos voltar quando não tivéssemos certeza de nossos passos. Elas não nos diziam nada sobre o como fazer e nem nos ofereciam uma conceituação segura, mas serviram como convites e como bússolas podendo nos (re)colocar no caminho e nos fazer lembrar daquilo que estávamos buscando. Poderíamos dizer uns às outras, por exemplo, "lembram-se da tirinha tal?"

São muitas as reflexões que alunos, alunas e professora fizeram a partir das obras. Vamos relembrar aqui apenas algumas delas sem nomear todos os seus autores e autoras. Em primeiro lugar, a vida que aparece nas obras é uma vida em

Acesso em 11 un. 2021

${ }^{11}$ https://www.youtube.com/watch?v=7QgnGm9wR4M 
permanente devir e transformação. Para acompanhá-la - como artista - não podemos querer paralisá-la, fixá-la, há que compreender esse fluxo contínuo, há que compreender-se também em transformação.

A vida que aparece nos desenhos e na música é também uma vida que acolhe seres vivos e não vivos - folha e vento, por exemplo, fazem parte de um mesmo mundo que dança e do qual a menina, tendo se dado ao tempo de percebê-lo, deseja - sua pergunta pode ser entendida assim - participar. Ela quer encontrar o professor ou a professora daquela folha, quer conhecer a sua escola. A aluna Maria Clara Migliora, após ver esta tirinha, se pergunta como seria se, no próximo quadrinho, a menina se propusesse a dançar com a folha (ou como a folha), e, assim, com o vento. E, porque atriz, se pergunta ainda: como seria aprender sobre a vida da cena com as coisas, os outros seres e seus modos de estar? Talvez, respondem alguns estudantes, a menina já estivesse, de certa maneira, dançando com a folha, na medida em que, ao observá-la, tinha percebido tratar-se de uma dança. Esta percepção nos faria ver que a menina já estava imersa em um mundo em fluxo e coabitação. Muitos atores confundem ação com um estar em movimento, com fazer coisas, todavia a ação está "relacionada a modificações subjetivas - psicofísicas - engendradas por contatos" e relações. Ao entendermos que a vida não é realizada por mim, mas passa permanentemente por mim, podemos compreender como na paragem é possível haver uma série de ações. Ao invés de pensarmos como realizar uma cena ou ação viva, talvez devêssemos nos perguntar sobre como não bloquear o que já se passa, o que já dança no mundo e em nós.

No desenho de Manoel de Barros, não há separação entre os seres: trata-se de um homem ou de uma árvore? Trata-se de um braço ou de um galho onde pousam passarinhos? No desenho, aparece uma vida tão porosa que já misturada; uma vida onde se perdem as nomeações acostumadas perdendo-se, assim, as identidades recortadas. Todos podemos lembrar desta operação nos textos de Manoel de Barros. Ela vai além dos seres vivos, abarcando os fenômenos naturais - madrugada, sol, rio, pedra - e mesmo as coisas - latas, pentes.

Whiverson Reis, um dos monitores da disciplina, comentando o desenho de Manoel de Barros e lembrando-se de uma experiência vivida em sua infância, 
perguntou-se em voz alta: “como ser um lugar em que o pássaro pousa na gente?” Como ajustar-se, como pessoa, para ser uma quase árvore, permitindo, assim, que o pássaro se aproxime? Que metamorfose seria essa? A professora aproveitou a questão, trazendo-a para o contexto da contracenação: como me aproximar, enquanto ator e atriz, de meus parceiros de cena e criar condições de contato, de estar junto, como permitir que o outro realmente se aproxime? Falou-se da importância de um modo de ser/estar que fosse passivo, receptivo - ou, como diz Bondía, que padecesse aos acontecimentos. O bolsista de Iniciação Científica, Marcelo Miguez, lembrou ainda que para ser "visitado" por outros seres, para chegar a ser aquele lugar no qual "pássaros podem e querem pousar", o ator não deve se apegar, aprisionar essas visitações (não deve colocar os pássaros em gaiolas), mas entender-se como espaço de passagem. Os pássaros e seus vários nomes - relação, sensação, emoção, associação, memória, imagem - pousam e, algum tempo depois, quando querem, vão embora e devem poder ir. Miguez lembrava-nos dessa vida que ocorre a cada momento, e de um ator que, reconhecendo-a, não busca nem reter o que já passou e nem antecipar algo que ainda não está - seja literalmente, seja virtualmente - lá.

Na bela letra de Gilberto Gil, a vida e a arte aparecem como uma rede de afetações: a partir de um sopro ou energia divina, vinda não dos céus, mas de debaixo do chão, chegam ondas que se transformam em música e dança, que se lançam impulsionando sanfona, coração e trança de cabelo. Aqui o deus faz dançar todas as coisas, dando ritmo a corações e instrumentos, a sensações (esperança, alegria) e passos. Através deste ritmo, as coisas, pessoas, sensações e ações encontram-se ligadas umas às outras. A vida que aparece na música de Gil conecta coisas e seres através de algumas ondas energéticas, rítmicas. E através de algum deus.

Todas essas imagens, perguntas, reflexões, nascidas das obras foram retomadas em diversos momentos do curso. Elas reapareceram, por exemplo, em questões vinculadas à aprendizagem: quais os modos de apreender/ensinar que podem bloquear a vida, e quais aqueles que, ao contrário, poderiam liberá-la no interior das estruturas, sejam exercícios, cenas, treinamentos? E ainda sobre a vida da cena: será ela protagonizada pelo ator/atriz ou ela encontra-se em lugares mais 
insuspeitados nos quais a atriz é ela também partícipe? Essas obras nos ajudaram a pensar a vida tout court e a vida da cena a partir de palavras como contato, fluxo, ritmo, imersão e coexistência. Elas também foram estímulos para criarmos os nossos presentes. Vamos ver alguns deles (abram os links!)

Como dissemos, os presentes nasceram na periferia do primeiro curso ministrado, que seria, a princípio, eminentemente teórico. O que se buscava com as primeiras experiências para casa era apenas que as questões discutidas em sala pudessem ganhar uma pequena materialidade criativa. Esse continuou sendo o nosso intuito com o decorrer do tempo, mas essas experiências foram ganhando centralidade e começamos a nos interessar sobremaneira pela própria relação entre percepção e criação. Vamos seguir aqui um pouco desse caminho feito nas disciplinas. Começamos com a primeira experiência - quando ainda nem se sabia que outras viriam na sequência. Chamava-se "os seres desimportantes e as coisas desimportantes".

O título da atividade foi retirado do poema de Manoel de Barros "O Apanhador de Desperdícios", que havíamos lido e discutido em sala de aula. O poema diz assim:

Uso a palavra para compor meus silêncios.

Não gosto das palavras

fatigadas de informar.

Dou mais respeito

às que vivem de barriga no chão

tipo água pedra sapo.

Entendo bem o sotaque das águas

Dou respeito às coisas desimportantes

e aos seres desimportantes.

Prezo insetos mais que aviões.

Prezo a velocidade

das tartarugas mais que a dos mísseis.

Tenho em mim um atraso de nascença.

Eu fui aparelhado

para gostar de passarinhos.

Tenho abundância de ser feliz por isso.

Meu quintal é maior do que o mundo.

Sou um apanhador de desperdícios:

Amo os restos

como as boas moscas.

Queria que a minha voz tivesse um formato

de canto.

Porque eu não sou da informática:

eu sou da invencionática. 
Só uso a palavra para compor meus silêncios.

(Barros, 2003. p.34)

Citamos o texto completo, porque foi da leitura do poema que nasceu a atividade e, assim, talvez o leitor/a leitora compreenda melhor o que buscávamos. O convite era para que nas suas casas, em um momento escolhido do dia, o estudante parasse - sentado ou em pé, olhos abertos ou fechados -, percebesse sua respiração, tranquilizando-se nessa percepção. Depois, deveria voltar à atenção para o seu corpo, percebendo seu contorno no espaço, relacionando-se com seu peso e percebendo a relação com os apoios. Por último, era convidado a voltar sua atenção para a temperatura do ambiente e de seu corpo e para os possíveis movimentos à sua volta. Esse trabalho deveria demorar alguns bons minutos. Logo após, o estudante iria observar com calma e por um tempo prolongado a sua própria casa:

- os sons da casa;

- as cores da casa ou dos objetos da casa;

- as formas da casa ou dos objetos da casa;

- os contornos da casa ou dos objetos da casa;

- os diferentes tipos de chão ou teto da casa;

- os diferentes seres não humanos da casa: plantas, animais, insetos.

Ou seja, olhar para onde não se olha normalmente: aqueles lugares, coisas e seres que consideramos em geral desimportantes. E, principalmente, olhar para fora, ensaiando, pelos instantes que durasse a observação, uma diminuição do diálogo incessante que fazemos o tempo todo conosco [esta observação sobre a diminuição do diálogo interno apareceu mais como sintoma relatado pelos estudantes do que como solicitação inicial]. Depois, era solicitado que aquela observação pudesse se deter ainda mais, escolhendo uma das possibilidades elencadas na atividade - sons, formas, cores, seres - para observar por um tempo ainda maior. A partir dessa percepção (que a professora nomeou, na esteira das leituras de Manoel de Barros, de "um tempo voltado a inutilidades"), o estudante era convidado a fazer um pequeno presente para turma. Na atividade, levantavam- 
se possibilidades para este presente:

- escrever um pequenino texto;

- desenhar ou pintar algo;

- fazer uma foto ou série de fotos;

- fazer um pequenino vídeo;

- falar um pequeno texto seu ou de outro (e filmar-se falando);

- dançar uma pequena dança ou explorar alguns movimentos (e filmar- se dançando ou movimentando-se);

- ou outra coisa que você imagine como presente...

Depois, o presente era postado no mural de nossa sala virtual ${ }^{12}$. Importante dizer que, mesmo após o envio, a estudante poderia retornar a seu presente e refazê-lo quantas vezes desejasse a partir das discussões e análises realizadas em sala de aula ou a partir de novas descobertas que, porventura, ele mesmo fizesse. Um estudante também poderia partir de um presente que não fosse o seu para desenvolver o processo de criação. Assim, começamos um caminho sem volta, carregados por nossa curiosidade em torno da relação entre uma percepção alargada, silenciosa, sensível e os processos e resultados criativos que dela poderiam advir. O que brotaria desta percepção ou desta escuta?

Talvez, o primeiro presente relacionado àquela atividade e postado em nosso mural tenha sido o de Nínive Kienteca: https://youtu.be/mUXPQ Ye670

Kienteca encantou-se pelas formigas de sua casa. Diz ter olhado para elas por muito tempo. Ao invés de uma observação objetivante, falava que, após algum tempo, percebeu-se junto com os movimentos das formigas, com curiosidade pelos detalhes de suas relações, por seus ritmos, percebendo também, como em um zoom out, a relação com o espaço no qual elas se movimentavam. No vídeo de um minuto, foi o que vimos: formigas andando em uma parede branca. Desde

${ }^{12}$ A plataforma utilizada pela turma foi o Google Classroom. Nela, há um mural no qual os discentes podem postar materiais diversos. Inclusive, essa foi uma solicitação da professora desde o começo: que utilizássemos o nosso mural como espaço laboratorial, colocando impressões ou registrando textos, imagens ou outros "achados" que tivessem a ver com as questões estudadas. Nosso mural recebeu músicas, filmes, poemas dos próprios estudantes, imagens e fotografias de diferentes artistas etc. 
o início elas estavam lá e, também, a sua prévia nomeação: eram formigas andando e não parecia que nenhuma novidade iria nos surpreender. Mas, e se vencêssemos essa primeira nomeação e nos permitíssemos ficar com as formigas naquele minuto, como Kienteca tinha feito por um tempo ainda maior? $O$ que veríamos, sentiríamos, perceberíamos? Como podemos deixar que os seres que nos rodeiam nos ensinem outros modos de estar, como deixar que ajam sobre nossa percepção ou como observá-los sem imediatamente categorizá-los e, assim, cansarmo-nos deles, dando-os por conhecidos? Essa percepção poderia ser compartilhada? Para os que recebiam os presentes, tratava-se, então, de investigar de que modo nossa percepção operava normalmente e permitir-se ensaiar outros modos do sentir: em primeiro lugar, simplesmente tentar permanecer com o que se apresentava a nossos olhos e sentidos. E ver o que acontecia.

Essa nova sensibilização tinha desdobramentos micropolíticos, pois, como diz Pedro Sanches, "se a constante estimulação banaliza experiências e se essa banalização serve a uma economia do consumo, na medida em que alimenta a necessidade por sensações "novas" e sempre mais intensas, voltar-se ativamente para as coisas invisibilizadas rompe esse ciclo [...]. Nesse sentido, a atuação sobre o modo como percebemos o mundo e as coisas cotidianas têm implicações políticas de grande importância” (Sanches, 2020, p.362).

O presente da aluna Isabelle Cardoso, a partir desta mesma atividade, foi este vídeo: https://youtu.be/hFiczadi eU

Ela diz que começou a descobrir esse presente caminhando pelo espaço, percebendo o chão. Então, começou a pensar nos pés como seres desimportantes quando comparados ao rosto, aos braços e às mãos, sempre mais convocados quando se trata de expressividade. Ela começou a brincar com seus pés, dar atenção a eles, percebê-los e senti-los na relação com o chão, com o espaço: por onde eles caminham, o que sentem?

O presente de Cardoso causou-nos a todos uma forte impressão. Começamos, então, a pensar sobre ele minuciosamente. A primeira coisa que percebemos foi uma espécie de coexistência entre a música, os sons vindos do 
próprio movimento, o espaço, a luz e o corpo (ainda que deste só víssemos os pés e a sombra na parede). Parecia-nos que a estudante estava imersa nas relações que se formavam e se transformavam. Algo a movia, que não dizia só respeito a ela mesma e a sua vontade inicial de investigar os seus desimportantes pés. Parecia-nos que ela tinha percebido e acolhido a sombra na parede, bem como a luz que entrava pela porta, em sua dança e, também, que havia uma relação com os ritmos e melodia vinculados à música que tocava. Cardoso parecia estar permanentemente transformando a sua dança: Tratava-se de uma justa adaptação às relações visíveis e invisíveis que ocorriam a cada momento.

Ao refletir sobre a "dança dos pés", Whiverson Reis disse: "Uma coisa que ficou muito marcada para mim foi o lugar dos ritmos e do fluxo. Não havia um lugar de parada, de corte, embora houvesse lugares de paragem no movimento. Havia movimentos muito rápidos, super incisivos e outros momentos lentos, diferentes, mas, mesmo assim havia algo que sempre continuava; Isabelle não interrompia o fluxo, ela encontrava um lugar de continuidade, que parece muito justo com o que estava acontecendo. [...] me parece que o que surgia nascia sempre de uma atenção aberta, aberta ao que o som está fazendo no espaço, e no corpo dela, aberta às luzes e sombras, aberta às parcerias”. Percebíamos que o movimento corporal nascia do movimento perceptivo, que o centro do movimento de dança não era o corpo da atriz e nem mesmo seus pés. Na realidade, não havia um centro da ação, já que vimos que a percepção pode passar por diversos lugares sem perder seu próprio fio condutor e pode operar num entre mundos feito de luzes, sons e corpos.

O título da segunda atividade era grande: "Primeiro prepara-se a água e depois colocam-se os peixes e não o contrário [...] Por que nos focamos somente na 'vida do homem' e pouquíssimas pessoas perdem tempo ou pensam na 'vida do ambiente’?” (Alschitz, 2017). Tratava-se de uma frase de Jurij Alschitz, retirada de seu livro "Treinamento para Sempre".

Nesta atividade, os estudantes eram convidados a perceber a relação entre os ambientes da sua casa e seus habitantes constantes ou momentâneos: os objetos e mobílias, animais e humanos, mas também as correntes de ar, os cheiros, o vento, os diferentes momentos de uma iluminação externa, etc. Havia 
ainda a indicação de que antes de entrar ou ao sair de cada cômodo, o estudante deveria perceber os rastros deixados pela passagem de outros habitantes ou pela sua própria passagem: o que o espaço nos conta sobre a presença de alguém que por ali passou? Deveria perceber também a iluminação, a ventilação, a temperatura do lugar de onde saíra ou onde iria entrar.

Queríamos, nessa segunda atividade, aprofundar e circunscrever a primeira atividade realizada. Interessamo-nos pela possibilidade de os estudantes estabelecerem uma relação menos utilitária e mais sensível e poética - ainda que evitássemos conscientemente a auto projeção e o antropomorfismo - com o lugar onde vivem, com os diferentes ambientes da sua casa ou apartamento, com as coisas e objetos que lá se encontram ou que por lá passaram ou passam.

Gostaríamos de comentar, na relação com esta atividade, o presente da estudante Beatriz Charles. Mas, antes, vamos apresentar, para a contemplação de vocês, um conjunto de fotos de Reis e uma foto de Miguez, que também nasceram nesta atividade.

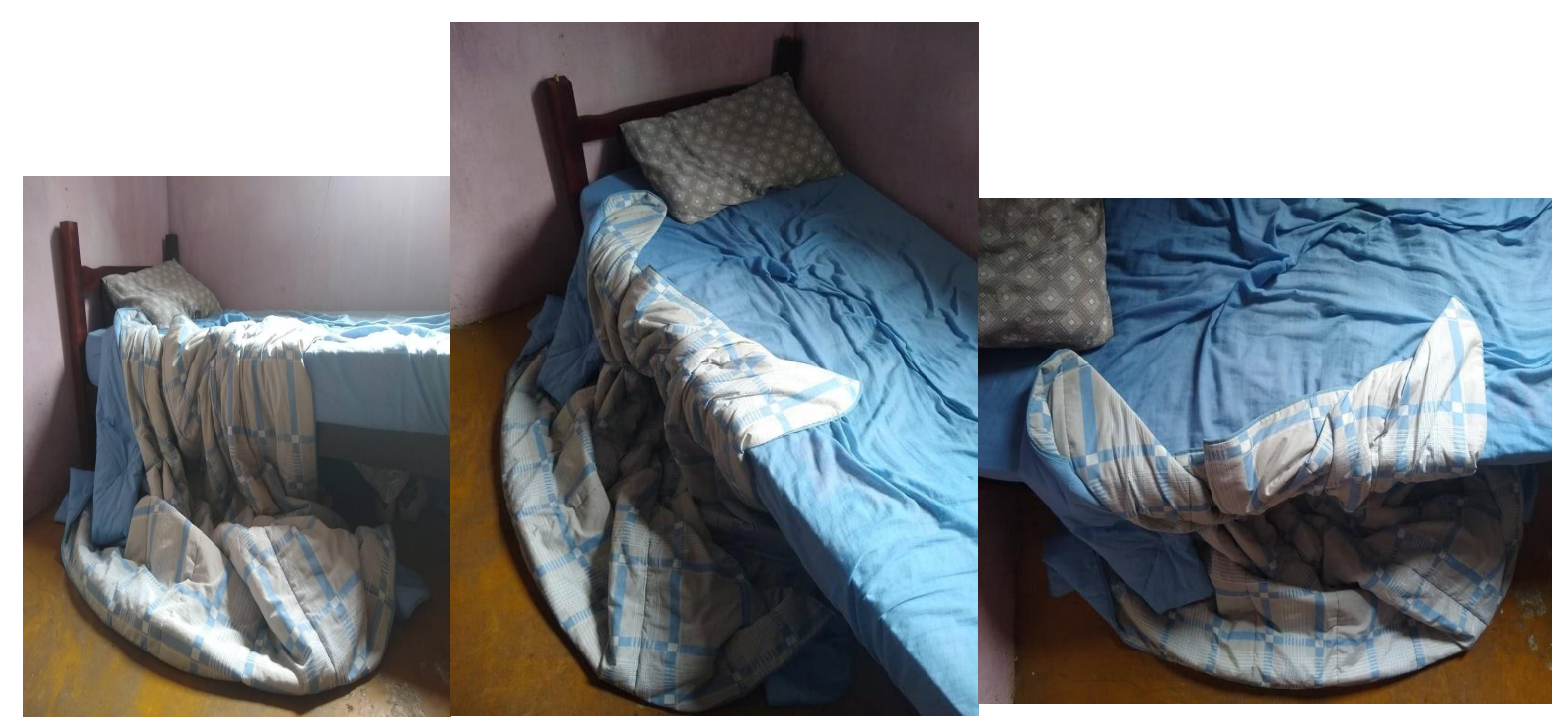




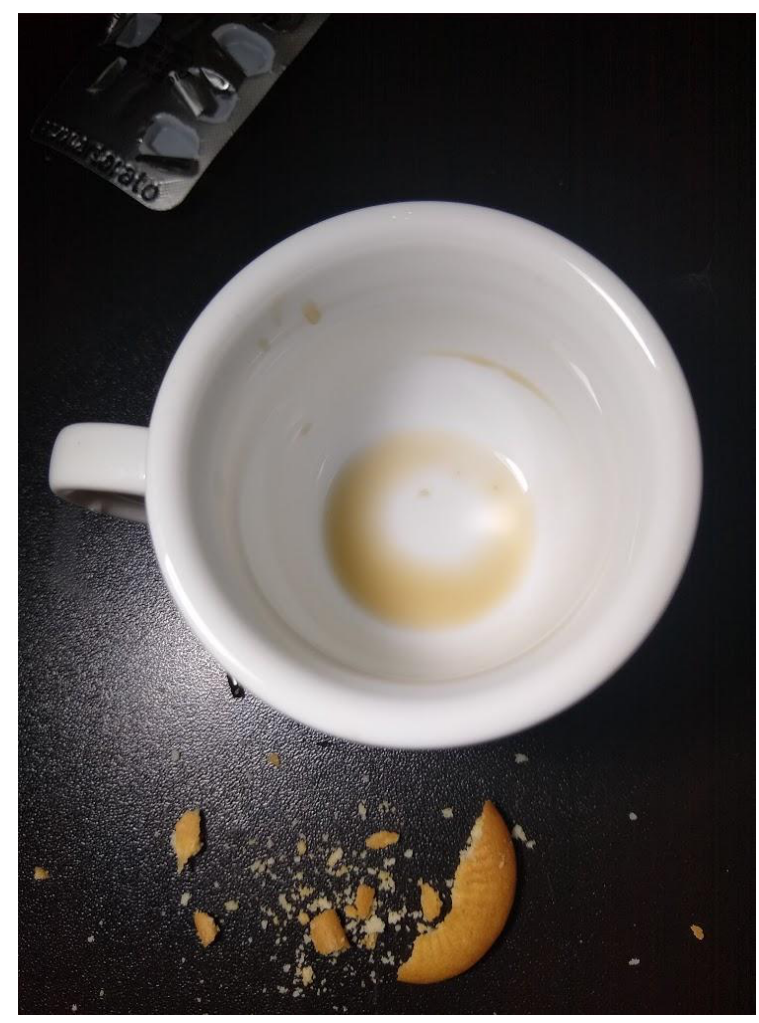

Figura 7 - Xícara, café, biscoito e remédio Marcelo Miguez

Já Beatriz Charles, como presente, nos trouxe este seu poema:

Eu sou grande demais

O espaço que meu corpo ocupa na cama

Que agora se nota um buraco maior do que seria confortável pra minha coluna, me diz isso

A junção de todos os átomos do meu corpo

Que formam a matéria que digere a minha realidade

Não são conscientes de si

Só quando eu os confronto com meu quarto vazio

E os coloco em referência a minha mão estendida

Tenho a oportunidade de observar e absorver a materialidade da minha alma

Mas eu vou tirar o eu da questão

Eu não acredito em pessoas que começam suas frases com a palavra eu Ela me tirou do foco

O foco é a minha cama quebrada, que ocupa o maior espaço do quarto Que me lembra a efêmera ação do tempo

Esse que não depende de mim, age em mim

Percebo o mundo com meus sentidos

É difícil de observar sem absorver

Eu inundo os espaços de eu

O meu quarto agora se enche de sentidos que só são entendidos por mim

Eu estou cheia de mim

A minha cama ficou tão cheia de mim que está afundando. 
No debate em sala de aula sobre este último presente, reapareceu um dos motes da disciplina, a pergunta sobre a possibilidade e interesse de um "sair de si”. O poema de Charles lida com esse tema de maneira bem-humorada, na medida em que escreve exatamente sobre os caminhos da (sua) percepção. Ela nos permitia perceber - de maneira não moralista ou dogmática - o que pode ocorrer no sujeito a partir do momento em que este desloca sua atenção, antes autocentrada, para o que não é 'eu' (no caso do poema, para o espaço, a cama, o quarto). Contraditoriamente ao que poderíamos pensar, esse deslocamento não afasta o sujeito de si mesmo, mas recoloca-o em um espaço mais amplo, diverso daquele introspectivo ou psicológico. Na poesia, a aluna circula entre cama, quarto, espaço, corpo, alma, átomos reconhecendo as relações que existem entre estas instâncias. Estes saltos perceptivos dão a ver uma relação entre a materialidade e a alma das coisas, sejam estas a mobília ou o corpo humano. Há, ainda, no poema, diferentes "si mesmas" que brotam nas diferentes maneiras de percepção do mundo. Não é o caso de analisar o poema em pormenores, mas gostaríamos de assinalar como sua criação está relacionada com uma percepção menos normalizada das coisas e menos autocentrada e autorreferente. O poema deixa claro que quando nos referimos à percepção não estamos falando nem de um olhar apenas para o exterior nem de um movimento introspectivo, mas dos atravessamentos, deslocamentos e continuidades entre essas instâncias.

Não será possível citar todas as atividades propostas "para casa”. Fiquemos com mais duas que consideramos importantes. A primeira chamava-se "parar no espaço e durar no tempo". Ela consistia em realizar algumas paradas - stops durante as atividades cotidianas. Criar conscientemente momentos nos quais paramos o que estávamos fazendo. Como seria perceber a vida nesses momentos de paragem? Envolvidos com nossas tarefas e pensamentos, esquecemos de deixar viver em nós aquela parte que silencia e pode testemunhar o que se passa. Nestes stops, essa percepção tinha a oportunidade de ser acordada. Perguntávamos: se pararmos o nosso corpo e, com ele, conseguirmos ralentar, por algum tempo, o fluxo rápido, ininterrupto e muitas vezes acusatório dos nossos pensamentos, se nos permitimos apenas olhar, ouvir e perceber, o que será que 
ouviremos, veremos, perceberemos? Importante dizer que esta percepção não necessita, para existir, destas paradas completas que fazíamos. Essa espécie de testemunho pode ser realizada em movimento. Em uma outra atividade, que não teremos espaço para comentar aqui, buscamos nesta direção, nos provocando com a pergunta que nomeava a atividade: "Parar e dançar são a mesma dança?". Presentes foram criados a partir destas paragens.

Por último, gostaríamos de comentar uma outra atividade: o pedido era para que se preparasse um presente nascido da relação com um texto de Manoel de Barros previamente escolhido pelo estudante. Dizíamos que era como se o autor tivesse oferecido um primeiro presente - o seu poema - à estudante que deveria recebê-lo (escutá-lo, percebê-lo) e retribuir ao poeta.

Valentina Carcano, também monitora nas disciplinas, criou seu presente como retribuição ao poema “Latas". Primeiro, vamos ler o poema:

\begin{abstract}
Estas latas têm que perder, por primeiro, todos os ranços (e artifícios) da indústria que as produziu. Segundamente, elas têm que adoecer na terra. Adoecer de ferrugem e casca. Finalmente, só depois de trinta e quatro anos elas merecerão de ser chão. Esse desmanche em natureza é doloroso e necessário se elas quiserem fazer parte da sociedade dos vermes. Depois desse desmanche em natureza, as latas podem até namorar com as borboletas. Isso é muito comum. Diferentes de nós as latas com o tempo rejuvenescem, se jogadas na terra. Chegam quase até de serem pousadas de caracóis. Elas sabem, as latas, que precisam chegar ao estágio de uma parede suja. Só assim serão procuradas pelos caracóis. Sabem muito bem, estas latas, que precisam da intimidade com o lodo obsceno das moscas. Ainda elas precisam de pensar em ter raízes. Para que possam obter estames e pistilos. A fim de que um dia elas possam se oferecer às abelhas. Elas precisam de ser um ensaio de árvore a fim de comungar a natureza. O destino das latas pode também ser pedra. Elas hão de ser cobertas de limo e musgo. As latas precisam ganhar o prêmio de dar flores. Elas têm de participar dos passarinhos. Eu sempre desejei que as minhas latas tivessem aptidão para passarinhos. como os rios têm, como as árvores têm. Elas ficam muito orgulhosas quando passam do estágio de chutadas nas ruas para o estágio de poesia. Acho esse orgulho das latas muito justificável e até louvável (Barros, 2003, p.44).
\end{abstract}

Agora, vejamos o vídeo feito pela estudante: https://youtu.be/nUQD173Ny1M

O estudante Robson Barreto, ao comentar o vídeo da colega, disse: "Você vê (e nos faz ver) muita vida, muitos organismos, muitos detalhes. [...]. Fazemos um 
passeio pela organicidade daqueles sistemas [...]”. Carcano, nesta filmagem, deixa que a sua percepção e seu movimento de corpo e câmera se guiem pela alteridade dos seres que ela acompanha - plantas, carro, bichos, árvores, céu. E nós mesmos já não sabemos muito bem o que somos, se homens, plantas, céu, carro enferrujado. A contemplação é cinestésica, sensual e não apenas visual. Foi justamente neste trabalho que muitos estudantes sentiram sua respiração alargar-se e aprofundar-se.

Ainda nesta atividade, em referência a outro texto de Manoel de Barros, conhecemos a Vó Jaci, avó da aluna Gabrielle Nogueira. O vídeo permite que o tempo de uma percepção silenciosa e alargada se instale em nós, espectadores: a avó não está destacada dos ambientes e sonoridades. Ao contrário: conhecemos a avó ao conhecermos o (seu) jardim, e vice-versa, conhecemos a avó ao percebermos o (seu) silêncio, e vice-versa. De alguma forma também, tanto o som da reportagem na TV (sobre a pandemia) quanto o som da voz da avó contando sua história de trabalho desde os 12 anos, pela forma que são apresentados, nos deslocam da avó de Gabrielle para tantas outras avós e para vidas que parecem valer tão pouco em nossa sociedade de passado escravista e na qual os mais velhos são, muitas vezes, considerados inúteis, seres desimportantes. Aqui, o vídeo: https://youtu.be/UiiSeqWWzws

Finalizamos, lembrando que (re)pensar nossos processos perceptivos (e, com eles, os processos de subjetivação e a atuação) foi o objetivo central das disciplinas ministradas. O desejo era de que tanto a parada forçada da pandemia quanto o deslocamento da sala de aula para dentro de nossas casas nos permitissem questionar modos de vida e criação que se relacionam, sem dúvida, com determinados regimes atencionais e modos de percepção. Buscamos propiciar através de textos, discussões e experiências - uma espécie de desnaturalização daqueles modos e regimes, chegando a poder sentir - e não só compreender que o individualismo e o utilitarismo de nossa sociedade neoliberal encapsulam nossa percepção e sensibilidade direcionando-a, monetarizando-a, padronizandoa, enfeitiçando-a numa suposta ideia de escolha, liberdade e produção. Compreendendo o impacto desse encapsulamento, ao enxergá-lo muitíssimas vezes em nós mesmos, tanto nos processos criativos quanto na vida cotidiana, 
desejávamos encontrar brechas para aproximarmo-nos de outros regimes perceptivos, ainda que provisórios, temporários.

Deixamos ainda, para apreciação de vocês, o vídeo que fizemos no final da disciplina de 2020.1 que reunia alguns presentes da turma:

\section{https://youtu.be/AWxrYreYDao}

Nossa função como artistas, professores e estudantes de artes é também o de imaginar outras possibilidades e buscar caminhos para uma vida em comum. Para isso, parece ser necessário um trabalho micropolítico, que busque desabituar determinados processos e desbloquear maneiras de estar e perceber que foram esquecidas e que podem (re)aparecer quando encontramos alguma saída de nós mesmos, quando silenciamos um eu que tudo quer controlar, nomear e expressar. Ao ampliar essas percepções, ficamos mais perto de algo que poderíamos nomear como um processo criativo, e, assim, talvez tenhamos possibilidade de imaginar um mundo diferente daquele no qual, mais frequentemente, vivemos. Podemos imaginar uma vida mais ampla - inclusive, a vida da cena - e atentar para o que é coexistir (esteja-se atuando ou não) em um mesmo planeta. A criação artística e a imaginação compartilhada de mundos outros podem ser vividos, assim, como processos amalgamados. E a arte é reaquecida como lugar de produção de um conhecimento que só se configura como transformação (de si).

O aluno Vitor Brito, na sua avaliação final, parece falar exatamente sobre isso: "[o curso foi sobre encontrar] a brecha dentro si para poder sair, e nessa saída olhar de fora, tendo a certeza de que valeu a pena num período tão sombrio, uma luz nos potencializar artística e intelectualmente".

O momento pandêmico, em sala de aula remota, convocou-nos a uma nova sensibilização, entendemos que era necessário olhar para este momento sem escaramuça, pânico ou romantização, pois, como também diz Manoel de Barros:

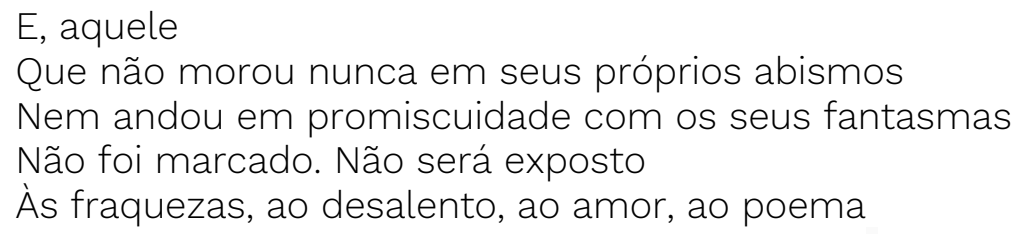

(Barros, 2010, p.82) 


\section{Referências}

ALSCHITZ, Jurij. Treinamento para sempre. São Paulo: Perspectiva, 2017.

BARROS, Manoel de. Memórias inventadas: a infância. São Paulo: Planeta, 2003.

BARROS, Manoel de. Memórias inventadas: a terceira infância. São Paulo: Planeta, 2008.

BARROS, Manoel de. Poesia Completa. São Paulo: Leya, 2010.

BONDÍA, Jorge Larrosa. Experiência e alteridade em educação. Tradução: Maria Carmen Silveira Barbosa e Suzana Beatriz Fernandes. Revista Reflexão e Ação, Santa Cruz do Sul, v. 19, n 2, p. 04-27, jul./dez. 2011. Disponível em: https://online.unisc.br/seer/index.php/reflex/article/download/2444/1898.

Acesso em: 08 jun. 2021.

BONDÍA, Jorge Larrosa. Notas sobre a experiência e o saber de experiência. Tradução: João Wanderley Gerald. Revista Brasileira de Educação. n.19, p. 20-28, jan./abr. 2002. Disponível em:

https://www.scielo.br/j/rbedu/a/Ycc5QDzZKcYVspCNspZVDxC/?lang=pt\&format=p df. Acesso em: 08 jun. 2021.

BROOK, Peter. Shakespeare é um pedaço de carvão. In: O ponto de mudança: Quarenta anos de experiências teatrais: 1946-1987. Rio de Janeiro: Civilização Brasileira, 1994.

CITTON, Yves. The Ecology of Attention. Cambridge: Polity Press, 2017

COCCIA, Emanuele. A vida das plantas: uma metafísica da mistura. Florianópolis: Editora Cultura e Barbárie. 2018.

DARDOT, Pierre; LAVAL, Christian. A nova razão do mundo: ensaio sobre a sociedade neoliberal. Tradução Mariana Echalar. 1. ed. São Paulo: Boitempo, 2016.

GROTOWSKI, Jerzy. Em busca de um teatro pobre. Rio de Janeiro: Civilização Brasileira, 1987.

HAN, Byung-Chul. Psicopolitica - O neoliberalismo e as novas técnicas de poder. Tradução de Maurício Liesen. Belo Horizonte: Editora Âyiné, 2018.

KRENAK, Ailton. A vida não é útil. 1o ed. São Paulo: Companhia das Letras, 2020.

LIVE com Vicente Franz Cecim sobre Viagem a Andara O Livro Invisível. Realização 
de Vianzza Tv. Pará, 2020. (210 min.), son., color. Disponível em: https://www.youtube.com/watch?v=WbtHbN8mDjk. Acesso em: 10 jun. 2021.

QUILICI, Cassiano. O Ator-Performer e as Poéticas da transformação de si. São Paulo: AnnaBlume, 2015.

SANCHES, Pedro. A Relevância Política de Alguns Princípios do Contato Improvisação. Urdimento - Revista de Estudos em Artes Cênicas, Florianópolis, v.1, n.37, p. 356-376, 2020.

SIMPÓSIO Práticas de Atenção - A Atenção na Experiência Estética e no Trabalho do Cartógrafo. Realização da Fundação Bienal de São Paulo, em parceria com o Sesc-Sp. 2018. Live (39 min.), son., color. Palestra de Virgínia Kastrup. Disponível em: https://www.youtube.com/watch?v=07vlatGHfSI. Acesso em: 10 jun. 2020.

SIMPÓsıo Práticas de Atenção - Por uma Política de Ruminação em Tempos de Dispersão Hiperconectada. Realização da Fundação Bienal de São Paulo, em parceria com o Sesc-Sp. São Paulo, 2018. Live (33 min.), son., color. Palestra de Maria Cristina Franco Derraz. Disponível em: https://www.youtube.com/watch?v=iGnl3ZTjhgU. Acesso em: 08 jun. 2021.

VAGAMUNDOS - Um Laboratório Cênico: Abrindo Terreiros - Cosmovisões Terra. Realização de Centro de Pesquisa Teatral - Sesc. São Paulo, 2020. Live (116 min.), son., color. Convidados na live: Ailton Krenak, Maria Thais. Disponível em: https://www.youtube.com/watch?v=G8LZd7nxd9w. Acesso em: 11 jun. 2021.

Recebido em: 15/06/2021

Aprovado em: 18/08/2021 